\title{
An Approach to the Evaluation and Classification of Dimensional Stone Quarries with an Emphasis on Safety
} Parameters

\author{
Mojtaba Yari ${ }^{1}$; Raheb Bagherpour ${ }^{\text {; }}$ Najmeddin Almasi ${ }^{1}$ \\ ${ }^{1}$ Department of Mining Engineering, Isfahan University of Technology, Isfahan, Iran
}

The Mining-Geology-Petroleum Engineering Bulletin UDC: 622.8

DOI: $10.17794 / \mathrm{rgn} .2016 .3 .2$

Original scientific paper

Abstract

Building, dimensional and decorative stones from mining and industry are among the significant resources of Iran. Following China and Italy, Iran is in third place of world production, but only has a minor contribution in international trade. One main reason of this problem is negligence regarding the introduction of dependable mines to foreign customers On the other hand, the frequency of fatal and non-fatal accidents in these mines implies the necessity of more attention to safety parameters. The first stage to attain this aim is identifying the major factors on safety of these mines and ranking the major mines considering these indices. In this paper, a comprehensive model for ranking of mines in the sense of all imposing attributes with an emphasis on safety parameters is presented In order to validate the model, 19 active mines of the Pyrtak Company in Lorestan province have been used In this paper, after determining all the parameters of safety in decorative stone mines and weighting these attributes, using AHP-TOPSIS and fuzzy environment, mines have been ranked. After a systematic evaluation of the decorative stone mines, the most appropriate mine is selected

\section{Keywords}

Dimensional stone; Multi Criteria Decision Making (MCDM); Quarry

\section{Introduction}

In terms of the quality and quantity of decorative and dimensional stones, Iran is considered one of the top 10 countries in the world. This country contains approximately 7.3 billion tons of known reserves of which 3.3 billion tons are proven reserves and the remainder are regarded as probable reserves. The Lorestan province is one of the richest provinces of Iran from the perspective of decorative stone and official statistics indicate that the Lorestan province holds about $3 \%$ of the world's decorative stones. The northeast region is part of the Sanandaj-Sirjan metamorphic zone which contains the area between the north of Boroujerd and the south of Dorud. Other parts of the region are situated in the Zagros Mountains. Structural differences and magmatic metamorphism phenomenon have divided the province into two East - West zones with different characteristics: the Sanandaj-Sirjan zone and the Zagros zone. Sanandaj-Sirjan contains alternating Middle Triassic-Paleozoic deposits including gray limestone and marble. All areas located to the west of the Chalancholan-Silakhor plain up to western part of the province are part of the Zagros sedimentary unit. Northern parts of the province cover the outcrops of Sanandaj-Sirjan. The metamorphic-magmatic zone of Sanandaj-Sirjan includes decorative stones and marble in the central and southern parts of the province. The presence of abundant sedimentary outcrops with a large thickness supply good sources for construction materials.

Obviously, by increasing the amount of production, the health and safety of staff and workers, the appropriate usage of natural resources and the optimization of mine recovery will all have a significant importance in the decorative stone industry (Price and Ombler, 2007; Smith, 1999). In other words, managers should enhance the safety of mines and Corresponding author: Mojtaba Yari m.yari@mi.iut.ac.ir 
minimize property damage and physical injury (Yong Jeong, 1999). The need for special equipment and machines for mining, diverse hazardous activities, requirement for the stabilization and strengthening of benches, behavioral factors of local rock and other problems in mining necessitate special attention to the evaluation and ranking of mining workspaces, especially under a unique management (Paul and Maiti, 2007).

Kinilakodi, by examining 31 different open pit and underground mines, is classified mines in 3 classes of excellent, intermediate, and poor performance in terms of safety, implementing the safety performance index (SPI) (Kinilakodi et al. , 2011). In order to develop crisis management, Wu established a classification system based on three factors of mining accidents, containing: emergencies, lack of information and complexity of the position. As a result of this research, mining events have been scored in three categories: conventional or routine events, accidents, semi routine and unusual events (Wu et al. , 2012). Ersoy studied the most common risks of decorative quarry in 10 Turkish mines and statistical studies of the risk occurrence rate in these mines approached a reliable relationship between the accident index and the index of safety and concluded that the most common accident at the quarry of decorative stones is wire tearing (Ersoy, 2013). Ural and Demirkol extracted minerals in collaboration with theInstitute of Turkey and analyzed fatal and non-fatal accidents at Turkish mines. Ural and Demirkol concluded that Turkish mines were situated at a lower level than the global average level and safety improvment should be noted (Ural and Demirkol, 2008). Looking from the perspective of human resource management and utilizing collected data over 5 years from Swedish mines and analyzing about 2400 accidents in these mines, Blank came to the conclusion that more seasonal workers than employees can lead to the reduction of safety in mines (Blank et al. , 1995).

In the past two decades, researchers have paid attention to elements of safety management including: hazard identification, the process of injuries and discovering the cause of accidents in order to reduce the risk (Khanzode et al. , 2012). Aside from safety and technical issues, the least damage to the ecosystem and environment must be considered in decorative stone mines. It is a notable point that, the pit of the mines and tailing dams can be one of the most serious environmental threats (Yavuz Çelik and Sabah, 2008). In this regard, researchers have attempted to provideeffective solutions to reduce the negative effects of this phenomenon.

In his research, Dumigous (2006) summarized all methods dealing with environmental issues in the mining industry (Damigos, 2006). Akbulut recommends that construction using stone mines wastes in asphalt factories can help remove the waste from the environment while making more effective use of mine wastes (Akbulut and Gürer, 2007). Neri noted the necessity of further environmental restoration in decorative stones and in this regard, an influential plan in the 3 fields consisting of design, implementation and management was proposed (Neri and Sánchez, 2010).

Undoubtedly, in order to achieve these goals, culture and education is important, along with the efforts of institutions and the Commissions of safety and environment agencies, issued instructions and guidelines, and the strengthening of administrative leverage all play a significant role. The vast majority of research is solely emphasized on one aspect of environmental issues and/or safety factors and exclusively covers several particular mines. Thus, there is no a comprehensive method for this purpose.

There are not a lot of investigations on the ranking and classification of mines in terms of safety and environmental attributes. In this paper, a new approach is presented for the classification of decorative stone mines. These rankings help mining companies, particularly in the sectors of health, safety and environmental management; convert their qualitative assessment to quantitative evaluation and reliable judgment.

In order to further illustrate and illuminate, the presented method has been implemented for the active mines of the Pyrtak Company in the Lorestan province. The geological map of the Lorestan province is shown in Figure 1. Results are entirely satisfactory and acceptable. This company operated for decades and now is responsible for 19 active mines in the south-east of the Lorestan province (http://lorestan.mim.gov.ir). 


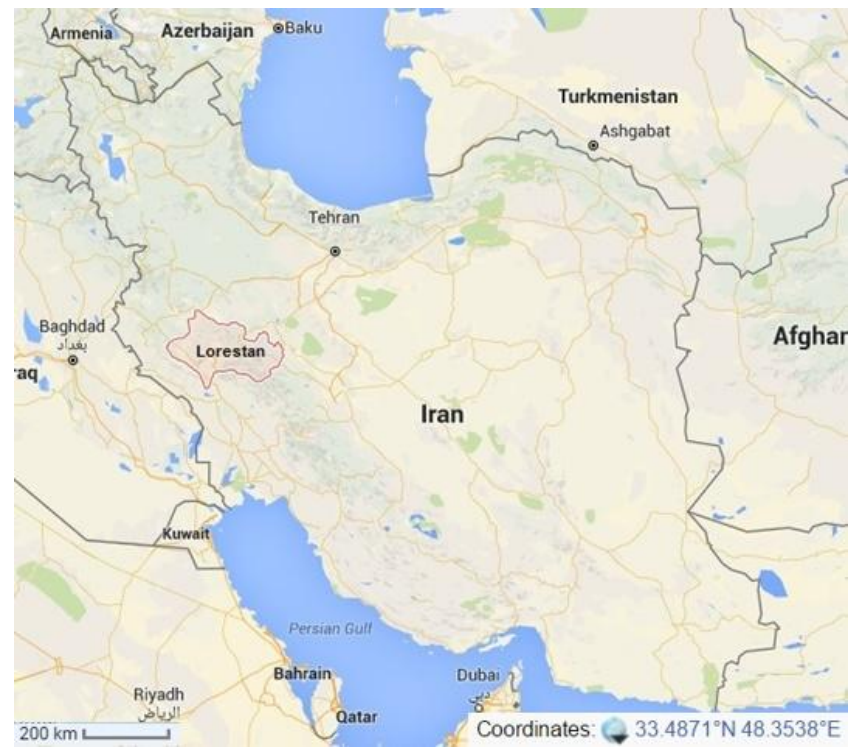

Figure 1. Geographical location of the Lorestan province

Through the advancement of human knowledge, the need for precise and scientific decision making while keeping in mind its sensitive nature, new decision making methods including Multi Attribute Decision Making (MADM) could find a suitable position in mining engineering. A selection of haulage equipment, Mining Method Selection (MMS), coal type ranking, support system selection, loading equipment choice, road header selection, ranking of risks in mines and ventilation assessment using new MADM or statistical methods of risk assessment have replaced traditional methods (Bazzazi et al. , 2011; Hekmat et al. , 2008; Lashgari et al. , 2011; Lashgari et al., 2012; Lashgari et al. , 2010; Mikaeil et al. , 2009; Yari et al. , 2015; Yari et al. , 2015; Yari et al. , 2013; Yari et al. , 2014; Yari et al. , 2015; Yarahmadi et al. , 2014). Finally, with regard to the above, it is necessary to be able to rank decorative stone mines upon different factors, considering the assessment of dimensional stone mines, and experts in MADM models. In this paper, the TOPSIS (Technique for Order of Preference by Similarity to Ideal Solution) method, which is one of the technical and applicable models of MADM, has been used for evaluating and ranking the alternatives and in the end, the most suitable alternative is selected.

\section{Multi Attribute Decision Making Methods}

MADM means that several aspects such as evaluation, prioritization and selection of the best available alternative are taken into account in the decision making process. In MADM problems; there are some alternatives which should be analyzed. Any problem also has several attributes which are specified for each alternative and the decision maker should define them accurately in the problems (Hwang and Yoon, 1981). The attributes in the decision matrix differ in terms of scale and unit. Sometimes, the attributes have a positive aspect and sometimes, they have negative feature. Therefore, a proper alternative will be the alternative which provides the best situation for each attribute (Lai, Liu, and Hwang, 1994).

\subsection{Evaluating the weight of attributes}

Decision making has several attributes of varying importance. Therefore, each attribute is given a weight and preference of for each index over other attributes. (Saaty, 1994). There are different methods such as Shanon Entropy, Analytical Hierarchy Process (AHP) and LINMAP for measuring the weight of the attributes, but considering its broad application, the AHP method is used most often.

\subsection{Analytic Hierarchy Process method}

The AHP method is presented based on the calculation of attributes in comparative priority. Comparative priority is obtained from different sets of criteria for comparison in an evaluation matrix while the overall priority is a final rank of 
each alternative. Here, the main goal of using the AHP method is only to calculate the weight of the attributes (Saaty and Vargas, 2001).

In order to prioritize the attributes, the first stage is choosing the criteria for comparison. In this regard, the arrays are compared with each other based on one criterion. In the process of this comparison, each attribute compares with other attributes and their relative degree of importance is determined with a number. In order for the comparison to take place, a matrix is formed where the attributes are written in rows and columns and each index is assessed over another index. In this process, each index receives the number 1 in relation to itself but other indexes are filled with their corresponding score, as can be seen in Table 1. This scoring is done by experts (Hwang and Yoon, 1981).

Table 1. Analytical Hierarchy Process (AHP) scale (Saaty, 1994).

\begin{tabular}{|rc|}
\hline Definition & Description \\
\hline Equally Preferred & Degree of importance \\
Moderately Preferred & One element is moderately Preferred over another element. \\
Strongly Preferred & One element is strongly Preferred over another element. \\
Very strongly Preferred & One element is very strongly Preferred over another element \\
Extremely Preferred & One element is extremely Preferred over another element. \\
& The intermediate values are determined with numbers 2, 4,6,8 in judgments. \\
\hline
\end{tabular}

When index ' $a$ ' compares with ' $b$ ', one of the numbers in the Table 1 is allocated to it. But when index ' $b$ ' compares with index ' $a$ ', the reciprocal of that number is allocated. Results are recorded in a matrix where rows and columns are attributes. It is evident that arrays of diameter of this matrix are 1 as fallow (Saaty and Vargas, 2001).

$$
\left[\begin{array}{ccccc}
1 & a_{12} & a_{13} & \ldots & a_{1 n} \\
1 / a_{12} & 1 & \ldots & \ldots & \ldots \\
1 / a_{13} & \ldots & 1 & \ldots & \ldots \\
\ldots & \ldots & \ldots & 1 & \ldots \\
1 / a_{1 n} & 1 / a_{2 n} & \ldots & \ldots & 1
\end{array}\right]
$$

In the AHP method, the weight of the attributes is determined so that Equation 2 holds true (Hwang and Yoon, 1981).

$$
\begin{aligned}
& \mathrm{a}_{11} \mathrm{~W}_{1}+\mathrm{a}_{12} \mathrm{~W}_{2}+\ldots+\mathrm{a}_{1 \mathrm{n}} \mathrm{W}_{\mathrm{n}}=\lambda \cdot \mathrm{W}_{1} \\
& \mathrm{a}_{21} \mathrm{~W}_{1}+\mathrm{a}_{22} \mathrm{~W}_{2}+\ldots+\mathrm{a}_{2 \mathrm{n}} \mathrm{W}_{\mathrm{n}}=\lambda \cdot \mathrm{W}_{2}
\end{aligned}
$$

$$
\mathrm{a}_{\mathrm{n} 1} \mathrm{~W}_{1}+\mathrm{a}_{\mathrm{n} 2} \mathrm{~W}_{2}+\ldots+\mathrm{a}_{\mathrm{nn}} \mathrm{W}_{\mathrm{n}}=\lambda \cdot \mathrm{W}_{\mathrm{n}}
$$

Where:

$a_{i j}$ - preference of the $i$-th element over the $j$-th element;

$\mathrm{w}_{\mathrm{i}}$ - weight of the $\mathrm{i}$-th element;

$\lambda$ - a constant.

Considering Equation 2, the weight of each attribute is:

$$
W_{i}=\frac{1}{\lambda \sum_{j=1}^{n} a_{i j} w_{j}} ; i=1,2, \ldots, n
$$

And Equation 4 can be written as $\mathrm{A} \times \mathrm{W}=\lambda . \mathrm{W}$

Where:

A - evaluation matrix;

$\mathrm{W}$ - weight vector;

$\lambda$ - a constant.

According to Equation 4, the weight of each index can be calculated. 
After choosing criteria for comparisin, consistency should also be calculated. The AHP method calculates the logical consistency and the priority of attributes. In case an inconsistency number is larger than 0.1 , the evaluation matrix is inconsistent and should be revised, and in case inconsistency is zero, the evaluation matrix is fully consistent. According to Saaty's research, the founder of the Analytical Hierarchy process, a consistency rate up to 0.1 is acceptable (Saaty, 1994).

At last, after calculating the weight of the attributes and solving the MADM model, a final ranking can be made.

\subsection{TOPSIS}

The TOPSIS model was proposed by Hwang and Yoon in 1981. This model has broad applications and is one of the best MADM models. In this method, the $m$ alternative is evaluated by the $n$ attribute and each problem is a geometrical system including the $m$ point in an $n$-dimensional space. In this technique, the most suitable alternative with a positive ideal solution (the best possible solution) has the shortest distance, and a negative ideal solution (the worst possible state) has the maximum distance. It is assumed that the value of each index is uniformly increasing or decreasing (Hwang and Yoon, 1981; Lai et al., 1994).

\subsection{TOPSIS steps}

In order to select the most suitable alternatives using the TOPSIS method, steps of this method are described as follows (Hwang and Yoon, 1981).

a. Evaluation matrix

Evaluation matrix is formed by considering the number of criteria and alternatives as in Equation 1.

$$
D=\begin{gathered}
C_{1} \\
A_{1} \\
A_{2} \\
A_{3} \\
\vdots \\
A_{m}
\end{gathered}\left[\begin{array}{rrrrrr}
x_{11} & x_{12} & x_{13} & \ldots & x_{1 n} \\
x_{21} & x_{22} & x_{23} & \ldots & x_{2 n} \\
x_{31} & x_{32} & x_{33} & \ldots & x_{3 n} \\
\vdots & \vdots & \vdots & \ddots & & \vdots \\
x_{m 1} & x_{m 22} & x_{m 3} & \ldots & x_{m n}
\end{array}\right]
$$

Where:

$A_{i}$ - the i'th alternative $(i=1,2,3 \ldots \mathrm{m})$;

$\mathrm{C}_{\mathrm{j}}$ - the $\mathrm{j}^{\prime}$ th criteria $(\mathrm{j}=1,2,3 \ldots \mathrm{n})$;

$X_{\mathrm{ij}}$ - value of the i'th alternative in the $\mathrm{j}^{\prime}$ th criteria.

b. Evaluation matrix normalization

In an evaluation making matrix, different attributes with different units and scales are usually placed next to each other. For logical comparison, it is necessary that these attributes be dimensionless and additive (Saaty, 1994). The norm method is the most common method for normalizing (Saaty and Vargas, 2001). In this method, each array of the evaluation matrix is divided by square numbers of arrays of each column as in Equation 5:

$n_{i j}=\frac{a_{i j}}{\sqrt{\sum_{i=1}^{m} a_{i j}^{2}}}$

Where:

$n_{i j}-$ the normalized value of the $i$-th alternative in terms of the $j$-th index;

$\mathrm{a}_{\mathrm{ij}}-$ arrays of matrix.

In this regard, all columns of an evaluation making matrix take similar units and they can be easily compared.

c. Normalized evaluation matrix

For comparison, one should consider the diverse weight of the attributes and form a normalized evaluation matrix.

Where:

ND - normalized matrix; 
Wn $\mathrm{x} \mathrm{n}$ - is a diagonal matrix in which only arrays of the main diagonal are non-zero (the relative weights of criteria are located on the main diagonal.).

d. Determining the positive ideal solution and negative ideal solution

Positive ideal alternative ( $\mathrm{V}+$ ) and negative ideal alternative (V-) are defined as Equation 7 and Equation 8.

$v^{+}=\left\{\left(\max _{i} v_{i j} \mid j \in J^{\prime}\right),\left(\operatorname{minv}_{i} \mid j \in J^{\prime}\right) \mid i=1,2, \ldots, n\right\}=\boldsymbol{u}_{i}^{+}, \boldsymbol{v}_{2}^{+}, \ldots \ldots, \boldsymbol{v}_{j}^{+}, \ldots \ldots, \boldsymbol{v}_{n}^{+}$

$v^{-}=\left\{\left(\min _{i} v_{i j} \mid j \in J^{\prime}\right),\left(\max _{i} v_{i j} \mid j \in J^{\prime}\right) \mid i=1,2, \ldots ., m\right\}=\hat{u_{1}^{\prime}}, v_{2}^{-}, \ldots \ldots . ., v_{j}^{-}, \ldots \ldots ., v_{n}^{-}$

e. Calculating the size of separation (distance)

Distance of the i-alternative from the ideal alternative using the Euclidean should be calculated in this stage.

Distance of the i-alternative of the positive ideal alternative is obtained as in Equation 9.

$d_{i+}=\left\{\sum_{j=1}^{n} \boldsymbol{\phi}_{i j}-v_{j}^{+}-\right\}^{0 / 5} ; i=1,2, \ldots, m$

Distance of the i-alternative from the negative ideal alternative is calculated by using Equation 10.

$d_{i-}=\left\{\sum_{j=1}^{n} \boldsymbol{\Lambda}_{i j}-\bar{v}_{j}^{-2}\right\}^{0 / 5} ; i=1,2, \ldots ., m$

f. Calculating relative closeness to the ideal solution

This relative closeness is defined as Equation 11.

$C L i+=d i-/(d i++d i-) ; 0 \quad C L i+1 ; i=1,2, \ldots, m$

If , then and we have and if , then and we have . Thus, when the alternative of is closer to the ideal solution ( , the value of is closer to the unit.

g. Ranking of alternative

Based on the descending order of , alternatives can be ranked and the most appropriate alternative can be selected.

\section{Methodology and the proposed model}

In all of the presented models up to now, there was no comprehensive method for safety evaluation among mines. Also, there was no serious attempt to determine all the affecting factors on the safety of building stone mines and this paper can be a great step for identifying the risks of these mines. In this paper, the AHP method is used for weighting the affecting parameters. The proposed model can be applied when ranking building stone mines, as shown in Figure 2. 


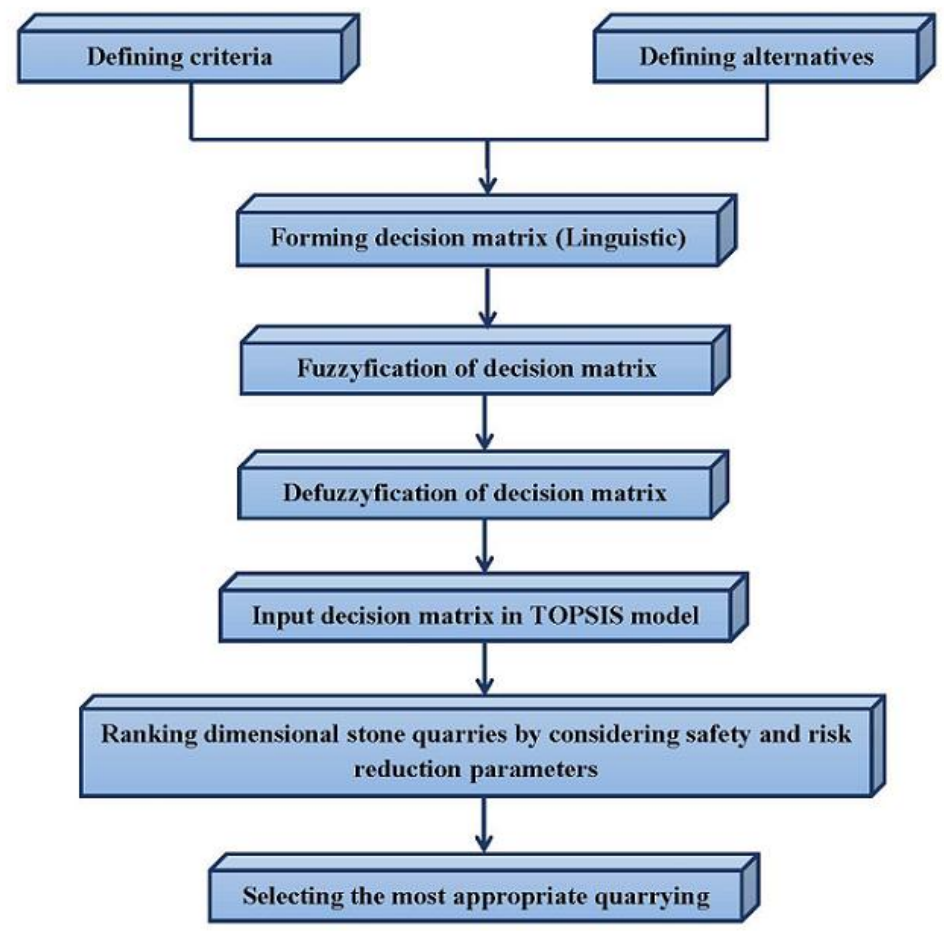

Figure 2. Flowchart of the proposed model for selecting the most appropriate dimensional stone quarry

In this process, all the parameters are linguistic variables. Firstly, the linguistic variables should be converted to crisp numbers. For this purpose, the fuzzyfication and defuzzification methods are implemented. Fuzzyfication is performed using triangular and trapezoidal fuzzy numbers in the Yager standard (Carlsson and Fullér, 1996). The Yager standard is illustrated in Figure 3.

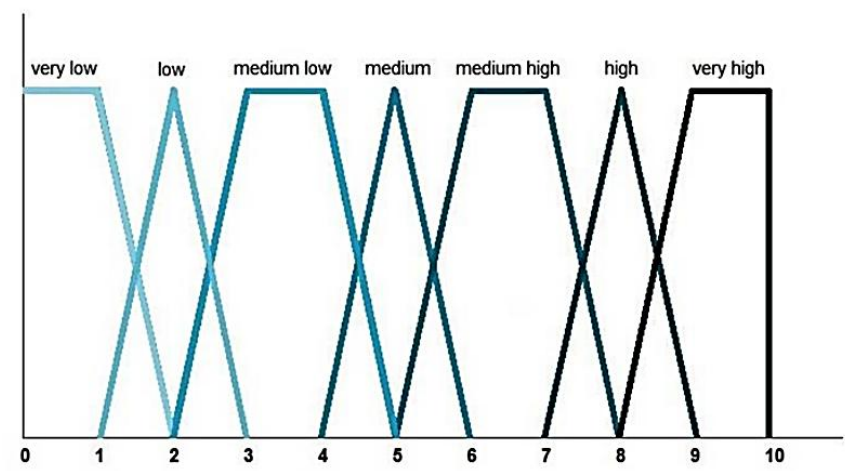

Figure 3. The Yager standard for converting linguistic variables to fuzzy numbers

Fuzzy numbers corresponding to each linguistic variable are shown in Table 2.

Table 2. The transformation of fuzzy membership functions

\begin{tabular}{|ll|}
\hline Linguistic variable & Membership function \\
\hline Very low & $(0,0,1,2)$ \\
Low & $(1,2,3)$ \\
Medium Low & $(2,3,4,5)$ \\
Medium & $(4,5,6)$ \\
Medium high & $(5,6,7,8)$ \\
High & $(7,8,9)$ \\
Very high & $(8,9,10,10)$ \\
\hline
\end{tabular}

Defuzzification has been implemented using the presented formula by Li and Lee (Stanley Lee and Li, 1993). These formulas are shown in Equation 12 and Equation 13. 
Triangular fuzzy number

$$
\mathrm{M}=(\mathrm{a}, \mathrm{b}, \mathrm{c})
$$

Trapezoidal fuzzy umber

$$
\mathrm{M}=(\mathrm{a}, \mathrm{b}, \mathrm{c}, \mathrm{d})
$$

Where:

$\mathrm{M}$ - a fuzzy number;

- the mean value of the fuzzy number that presents the final number.

After defuzzification, only crisp numbers in the data matrix remain and the TOPSIS decision making method can be employed.

\section{Evaluating Safety in mines of the Pyrtak Company using the presented model}

According to the presented flowchart in Figure 2, the proposed model is used for mines of the Pyrtak Company and steps were taken respectively. In the first stage, all influencing parameters on the safety of decorative stone mines are identified (see Table 3) and upon skillful experts' opinions, these attributes have been weighted regarding their impact on the safety of these mines (see Table 4).

In Table 5, the available alternatives have been mentioned in the first column of the left side, which includes 19 active mines. Each mine has been evaluated considering 22 attributes.

In order to calculate the weight of the attributes, it is essential to take pairs of attributes. This was done by a collection of 20 expert's views and calculating their consistency rate and synthesizing them logically.

For solving the MADM model, it is necessary to form an evaluation matrix consisting of 23 columns (A-V) and 20 rows (title row and 19 rows for mines 1-19) (see Table 5). The first column is the mine number for the mine being ranked. Other columns relate to the attributes. All alternatives along their attributes are recorded in Table 5.

In this paper, the ranking process can be applied to any set of both large scale and small scale problems. This collection includes 19 active mines that are entitled with individual names and licensed to extract.

\begin{tabular}{|c|c|c|}
\hline & Attributes & Description \\
\hline A & Personal Safety & $\begin{array}{l}\text { The basic parameters of personal safety include: helmet, safety shoes and } \\
\text { masks which are effective in preventing accidents }\end{array}$ \\
\hline B & Safety against incidents & $\begin{array}{l}\text { The creation of workplace accidents depends on negligence and inattention to } \\
\text { accidents in the workspace and not the creation of barriers to prevent } \\
\text { accidents that can cause human and financial events. }\end{array}$ \\
\hline $\mathbf{C}$ & Workplace improvement and defects fixing & $\begin{array}{l}\text { Workshops that have defects in mining operations and after recollection of } \\
\text { technical supervisors and experts tried to remove these deficiencies. Over } \\
\text { time will be converted to safe mines. }\end{array}$ \\
\hline D & Hygiene & $\begin{array}{l}\text { Hygiene and cleanliness of the workplace restaurants will reduce illness and } \\
\text { its consequences. }\end{array}$ \\
\hline $\mathbf{E}$ & Protecting the wire cutter & $\begin{array}{l}\text { In order to avoid throwing the torn wire segments, the protective covering is } \\
\text { required. }\end{array}$ \\
\hline $\mathbf{F}$ & Deployment of Equipment and Facilities & $\begin{array}{l}\text { Proper placement of machinery and electrical installations, selection of } \\
\text { suitable position for cutting, appropriate site selection for transformers and } \\
\text { electrical generators, etc. have a great impact on mine safety. }\end{array}$ \\
\hline G & Loosening up & $\begin{array}{l}\text { Harnessing the loose edges and falling edges and gaps that exist in wall have } \\
\text { a significant role on decorative stone safety. }\end{array}$ \\
\hline $\mathbf{H}$ & Bench opening & $\begin{array}{l}\text { Proper operation in special topographical conditions of mines, suitability of } \\
\text { the work development and bench preparation before extraction is an } \\
\text { important parameter in decorative mine safety }\end{array}$ \\
\hline I & Accessibility of mine & $\begin{array}{l}\text { Affecting parameters on this attribute are: having good access road to } \\
\text { extraction benches, accessibility of all steps and means of access to the mine } \\
\text { and Intercom benches }\end{array}$ \\
\hline $\mathbf{J}$ & Bench width & $\begin{array}{l}\text { For decorative stone which extracts open pit and using cut wire, appropriate } \\
\text { step width is within } 1.5 \text { to } 4 \text { meters in order to prevent the loss of upper stairs } \\
\text { and stabilization of steep stairs in the walls of the mine. Obviously reducing } \\
\text { the width of the stairs in the mine would be reducing safety. }\end{array}$ \\
\hline $\mathbf{K}$ & Bench height & Standard step height in open-pit mines, which are mined by wire cutting is \\
\hline
\end{tabular}

Table 3. Evaluation factors - continues on the next page

The Mining-Geology-Petroleum Engineering Bulletin, 2016, pp. 15-26 (C) The Author(s), DOI: 10.1177/rgn.2016.3.2 


\begin{tabular}{|c|c|c|}
\hline & & $\begin{array}{l}\text { about } 5 \text { to } 6 \text { meters. Increasing the height of the step leads to safety reduction } \\
\text { in the mine. }\end{array}$ \\
\hline $\mathbf{L}$ & Maneuverability of equipment & $\begin{array}{l}\text { Maneuvering space in the work space should be such that loading and haulage } \\
\text { equipment can travel easily on the mine floor and over stairs and have high } \\
\text { maneuverability. }\end{array}$ \\
\hline $\mathbf{M}$ & Bench status & $\begin{array}{l}\text { Appropriate form of the workplace, separate stairs and smooth walls, } \\
\text { perfectly distinct extractive space, controlling loose edge and loose up } \\
\text { hanging rocks enhances safety in mines. }\end{array}$ \\
\hline $\mathbf{N}$ & Equipment & $\begin{array}{l}\text { In decorative and building stone mines in order to facilitate the displacement } \\
\text { and loading of blocks, Carnes or Lift Truck are used, whichever is safer. }\end{array}$ \\
\hline $\mathbf{O}$ & Drainage & $\begin{array}{l}\text { All decorative mines of this province are located in the rainfall area, so } \\
\text { appropriate drainage can facilitate the production and increase safety. }\end{array}$ \\
\hline $\mathbf{P}$ & Providing the workshop & $\begin{array}{l}\text { Including use of safe equipment and facilities for displacement of blocks, } \\
\text { loading and haulage in order to reduce waste and enhance safety which } \\
\text { depends on the contractor's effort. }\end{array}$ \\
\hline $\mathbf{Q}$ & Technical supervisor activities & $\begin{array}{l}\text { Technical Supervisor's reports about technical and safety conditions help to } \\
\text { improve safety in the mine. }\end{array}$ \\
\hline $\mathbf{R}$ & Technical infractions & $\begin{array}{l}\text { Unauthorized use of explosives, non-compliance with safety regulations in } \\
\text { mines and mining operations without informing technical experts and } \\
\text { authorities is a key parameter in reducing accidents and safety in the } \\
\text { workplace. }\end{array}$ \\
\hline $\mathbf{S}$ & Waste dump situation & $\begin{array}{l}\text { This area should be out of the workshop and is below the surface of the } \\
\text { workshop. Access road to the site must have adequate width and be smooth in } \\
\text { order to ease transportation and safety of transportation. }\end{array}$ \\
\hline $\mathbf{T}$ & Environment destruction rate & $\begin{array}{l}\text { Workplace during quarrying, transportation and waste dumping destroys } \\
\text { environment and natural resources. }\end{array}$ \\
\hline $\mathbf{U}$ & Loading distance & $\begin{array}{l}\text { A smaller distance between the bench and loading platform lead to a safe } \\
\text { operation. }\end{array}$ \\
\hline $\mathbf{V}$ & Extraction efficiency & $\begin{array}{l}\text { This parameter indicates the monthly generated blocks under maximum } \\
\text { power of block generation. }\end{array}$ \\
\hline
\end{tabular}

Table 4. Weights of attributes

\begin{tabular}{|ll|}
\hline Attribute & Weight \\
\hline A & 0.002063 \\
B & 0.007253 \\
C & 0.007283 \\
D & 0.007283 \\
E & 0.039198 \\
F & 0.022368 \\
G & 0.013316 \\
H & 0.033609 \\
\hline
\end{tabular}

\begin{tabular}{|ll|}
\hline Attribute & Weight \\
\hline I & 0.065771 \\
J & 0.097571 \\
K & 0.097571 \\
L & 0.022110 \\
M & 0.010887 \\
N & 0.151644 \\
O & 0.017665 \\
P & 0.033933 \\
\hline
\end{tabular}

\begin{tabular}{|ll|}
\hline Attribute & Weight \\
\hline Q & 0.026276 \\
R & 0.014283 \\
S & 0.032662 \\
T & 0.032662 \\
U & 0.065324 \\
V & 0.160083 \\
& \\
\hline
\end{tabular}

Table 5. Evaluation matrix (linguistic variables) - continues on the next page

\begin{tabular}{|c|c|c|c|c|c|c|c|c|c|c|c|}
\hline & $\mathbf{A}$ & B & C & D & $\mathbf{E}$ & $\mathbf{F}$ & G & $\mathbf{H}$ & I & $\mathbf{J}$ & $\mathbf{K}$ \\
\hline Mine 1 & MH & MH & ML & $\mathrm{H}$ & $\mathrm{L}$ & MH & $\mathrm{H}$ & $\mathrm{H}$ & $\mathrm{H}$ & MH & VH \\
\hline Mine 2 & MH & MH & MH & $\mathrm{H}$ & VL & $\mathrm{L}$ & $\mathrm{H}$ & $\mathrm{H}$ & $\mathrm{H}$ & MH & $\mathrm{MH}$ \\
\hline Mine 3 & MH & MH & MH & $\mathrm{H}$ & VL & MH & ML & MH & $\mathrm{H}$ & $\mathrm{H}$ & $\mathrm{H}$ \\
\hline Mine 4 & $\mathrm{MH}$ & $\mathrm{MH}$ & $\mathrm{L}$ & MH & VL & MH & ML & $\mathrm{MH}$ & MH & ML & $\mathrm{VH}$ \\
\hline Mine 5 & MH & $\mathrm{MH}$ & $\mathrm{L}$ & $\mathrm{H}$ & VL & MH & ML & $\mathrm{H}$ & MH & $\mathrm{MH}$ & ML \\
\hline Mine 6 & MH & MH & VL & $\mathrm{H}$ & VL & ML & ML & MH & $\mathrm{H}$ & MH & $\mathrm{MH}$ \\
\hline Mine 7 & MH & MH & ML & MH & VL & MH & ML & MH & MH & ML & ML \\
\hline Mine 8 & ML & MH & ML & MH & VL & MH & ML & MH & MH & ML & VH \\
\hline Mine 9 & M & MH & $\mathrm{L}$ & ML & VL & ML & ML & MH & ML & MH & $\mathrm{H}$ \\
\hline Mine 10 & $\mathrm{M}$ & $\mathrm{MH}$ & ML & ML & VL & ML & VL & ML & ML & ML & $\mathrm{H}$ \\
\hline Mine 11 & M & MH & $\mathrm{L}$ & $\mathrm{H}$ & VL & ML & $\mathrm{L}$ & MH & MH & MH & $\mathrm{MH}$ \\
\hline Mine 12 & ML & MH & $\mathrm{L}$ & $\mathrm{H}$ & VL & ML & $\mathrm{L}$ & MH & $\mathrm{H}$ & ML & ML \\
\hline Mine 13 & M & MH & ML & $\mathrm{H}$ & VL & ML & ML & ML & ML & ML & VH \\
\hline Mine 14 & M & MH & VL & ML & VL & ML & VL & MH & ML & ML & $\mathrm{H}$ \\
\hline Mine 15 & M & $\mathrm{MH}$ & VL & ML & VL & $\mathrm{L}$ & $\mathrm{L}$ & $\mathrm{MH}$ & $\mathrm{L}$ & ML & ML \\
\hline Mine 16 & ML & M & VL & MH & VL & $\mathrm{L}$ & VL & MH & MH & $\mathrm{L}$ & MH \\
\hline Mine 17 & M & $\mathrm{MH}$ & VL & ML & VL & $\mathrm{L}$ & $\mathrm{L}$ & MH & $\mathrm{L}$ & $\mathrm{L}$ & $\mathrm{MH}$ \\
\hline Mine 18 & ML & $\mathrm{MH}$ & VL & ML & VL & ML & VL & ML & $\mathrm{L}$ & VL & $\mathrm{H}$ \\
\hline Mine 19 & ML & MH & VL & ML & VL & ML & VL & VL & VL & VL & ML \\
\hline
\end{tabular}




\begin{tabular}{|c|c|c|c|c|c|c|c|c|c|c|c|}
\hline & $\mathbf{L}$ & M & $\mathbf{N}$ & O & $\mathbf{P}$ & $\mathbf{Q}$ & $\mathbf{R}$ & $\mathbf{S}$ & $\mathbf{T}$ & $\mathbf{U}$ & V \\
\hline Mine 1 & $\mathrm{MH}$ & $\mathrm{H}$ & $\mathrm{H}$ & $\mathrm{MH}$ & $\mathrm{VL}$ & ML & $\mathrm{VL}$ & $\mathrm{H}$ & ML & $\mathrm{H}$ & $\mathrm{H}$ \\
\hline Mine 2 & $\mathrm{H}$ & ML & $\mathrm{H}$ & MH & MH & $\mathrm{L}$ & VL & MH & $\mathrm{L}$ & $\mathrm{H}$ & $\mathrm{H}$ \\
\hline Mine 3 & MH & ML & $\mathrm{H}$ & ML & ML & $\mathrm{MH}$ & VL & $\mathrm{H}$ & ML & MH & $\mathrm{H}$ \\
\hline Mine 4 & $\mathrm{H}$ & ML & $\mathrm{H}$ & ML & VL & MH & VL & $\mathrm{H}$ & ML & $\mathrm{H}$ & $\mathrm{VH}$ \\
\hline Mine 5 & MH & $\mathrm{VH}$ & $\mathrm{H}$ & MH & VL & $\mathrm{L}$ & VL & $\mathrm{H}$ & ML & MH & $\mathrm{H}$ \\
\hline Mine 6 & $\mathrm{~L}$ & MH & MH & ML & VL & ML & $\mathrm{L}$ & $\mathrm{H}$ & ML & $\mathrm{L}$ & ML \\
\hline Mine 7 & MH & MH & MH & ML & VL & ML & $\mathrm{L}$ & $\mathrm{H}$ & ML & $\mathrm{H}$ & MH \\
\hline Mine 8 & MH & MH & $\mathrm{H}$ & MH & VL & $\mathrm{MH}$ & $\mathrm{L}$ & $\mathrm{MH}$ & ML & ML & $\mathrm{H}$ \\
\hline Mine 9 & MH & MH & $\mathrm{H}$ & MH & VL & VL & $\mathrm{L}$ & ML & ML & MH & ML \\
\hline Mine 10 & $\mathrm{H}$ & MH & $\mathrm{MH}$ & MH & VL & $\mathrm{H}$ & MH & MH & ML & MH & MH \\
\hline Mine 11 & MH & MH & $\mathrm{H}$ & $\mathrm{L}$ & VL & $\mathrm{VH}$ & VL & ML & ML & L & MH \\
\hline Mine 12 & MH & ML & $\mathrm{H}$ & ML & VL & VL & $\mathrm{L}$ & ML & ML & MH & ML \\
\hline Mine 13 & $\mathrm{H}$ & $\mathrm{H}$ & $\mathrm{H}$ & $\mathrm{L}$ & VL & ML & M & MH & ML & ML & MH \\
\hline Mine 14 & ML & $\mathrm{H}$ & $\mathrm{H}$ & MH & VL & $\mathrm{MH}$ & $\mathrm{VH}$ & MH & ML & MH & MH \\
\hline Mine 15 & MH & ML & $\mathrm{H}$ & ML & VL & $\mathrm{VH}$ & M & $\mathrm{L}$ & MH & ML & MH \\
\hline Mine 16 & ML & MH & MH & ML & VL & ML & $\mathrm{L}$ & MH & ML & $\mathrm{L}$ & ML \\
\hline Mine 17 & ML & MH & $\mathrm{H}$ & ML & VL & ML & $\mathrm{M}$ & $\mathrm{H}$ & ML & $\mathrm{H}$ & $\mathrm{H}$ \\
\hline Mine 18 & $\mathrm{~L}$ & MH & $\mathrm{H}$ & MH & VL & VL & $M$ & MH & ML & ML & MH \\
\hline Mine 19 & MH & ML & $\mathrm{H}$ & $\mathrm{L}$ & VL & VL & $\mathrm{L}$ & MH & ML & $\mathrm{L}$ & MH \\
\hline
\end{tabular}

\section{Conclusion}

At the present time, all industries are trying to improve productivity, while simultaneously considering safety parameters in the workplace to achieve a stable production rate. In this regard, mining engineering is one of the most influential industries in the economy and as one of the most hazardous engineering fields, safety is particularly important. Decorative stone quarrying is one of the main branches of mining which requires the consideration of a lot of safety parameters for sustainable production. For this purpose, all fatal and non-fatal safety factors involved in the production rate should be identified and ranked. All in all, dimensional stone quarries need a comprehensive evaluation method considering all safety parameters. To achieve this goal, in this research a novel method has been presented for assessing and ranking these quarries and introducing the most appropriate one using MADM methods under a fuzzy environment. In the first step all affecting factors are determined using previous research and experts' opinions. According to this extensive and accurate ranking, extraction efficiency, equipment, bench width and bench height, respectively are the most important safety and technical parameters for stable production. After determining all the influencing factors on decorative quarries, evaluating and weighting these indices, a practical and extensible (for more mines) model is indicated for ranking dimensional stone mines. Finally, considering 22 affecting factors, the most suitable mine has been introduced among 19 active mines.

As extensive studies through many years regarding decorative stones show, there is no comprehensive model for classifying dimensional quarries in safety and sustainable production viewpoints. This paper is the first step of this research and researchers have spent more than 1 year gathering data and analyzing the results and developing a comprehensive model for ranking dimensional stone quarries. As a result, this comprehensive method can be used for evaluating all dimensional stone quarries by adding more alternatives around the world and there is no limitation for using this method in other countries and cases. By implementing this comprehensive model, scientists, managers and traders are able to evaluate dimensional stone quarries and choose the quarry with the more stable production rate.

\section{References}

Akbulut, H., and Gürer, C. (2007): Use of aggregates produced from marble quarry waste in asphalt pavements. Building and environment, 42, 1921-1930.

Bazzazi, A. A., Osanloo, M., and Karimi, B. (2011): A New Fuzzy Multi Criteria Decision Making Model For Open Pit Mines Equipment Selection. Asia-Pacific Journal of Operational Research, 28, 279-300. 
Blank, V. L., Andersson, R., Lindén, A., and Nilsson, B.-C. (1995): Hidden accident rates and patterns in the Swedish mining industry due to involvement of contractor workers. Safety Science, 21, 23-35.

Carlsson, C., and Fullér, R. (1996): Fuzzy multiple criteria decision making: Recent developments. Fuzzy sets and systems, 78, 139-153.

Damigos, D. (2006): An overview of environmental valuation methods for the mining industry. Journal of cleaner production, 14, 234-247.

Ersoy, M. (2013): The role of occupational safety measures on reducing accidents in marble quarries of Iscehisar region. Safety Science, 57, 293-302.

Hekmat, A., Osanloo, M., and Shirazi, A. (2008): New approach for selection of waste dump sites in open pit mines. Mining Technology, 117, 24-31.

http://lorestan.mim.gov.ir.

Hwang, C. L., and Yoon, K. (1981): Multiple attribute decision making: methods and applications: a state-of-the-art survey (Vol. 13): Springer-Verlag New York.

Khanzode, V. V., Maiti, J., and Ray, P. (2012): Occupational injury and accident research: A comprehensive review. Safety Science, 50, 1355-1367.

Kinilakodi, H., and Larry Grayson, R. (2011): A methodology for assessing underground coal mines for high safetyrelated risk. Safety Science, 49, 906-911.

Lai, Y.-J., Liu, T.-Y., and Hwang, C.-L. (1994): Topsis for MODM. European Journal of Operational Research, 76, 486-500.

Lashgari, A., Fouladgar, M. M., Yazdani-Chamzini, A., and Skibniewski, M. J. (2011): Using an integrated model for shaft sinking method selection. Journal of Civil Engineering and Management, 17, 569-580.

Lashgari, A., Yazdani-Chamzini, A., Fouladgar, M. M., Zavadskas, E. K., Shafiee, S., and Abbate, N. (2012): Equipment Selection Using Fuzzy Multi Criteria Decision Making Model: Key Study of Gole Gohar Iron Min. Engineering Economics, 23, 125-136.

Mikaeil, R., Naghadehi, M. Z., Ataei, M., and KhaloKakaie, R. (2009): A decision support system using fuzzy analytical hierarchy process (FAHP) and TOPSIS approaches for selection of the optimum underground mining method. Archives of Mining Sciences, 54, 341-368.

Neri, A. C., and Sánchez, L. E. (2010): A procedure to evaluate environmental rehabilitation in limestone quarries. Journal of environmental management, 91, 2225-2237.

Paul, P., and Maiti, J. (2007): The role of behavioral factors on safety management in underground mines. Safety Science, 45, 449-471.

Price, M., Ombler, G. (2007): The Sourcebook of Decorative Stone: An Illustrated Identification Guide: Firefly Books.

Saaty, T. L. (1994): Highlights and critical points in the theory and application of the analytic hierarchy process. European Journal of Operational Research, 74, 426-447.

Saaty, T. L., and Vargas, L. G. (2001): Models, methods, concepts and applications of the analytic hierarchy process (Vol. 34): Springer.

Smith, M. R. (1999): Stone: Building Stone, Rock Fill and Armourstone in Construction: Geological society London.

Stanley Lee, E., and Li, R. (1993): Fuzzy multiple objective programming and compromise programming with Pareto optimum. Fuzzy sets and systems, 53, 275-288.

Ural, S., and Demirkol, S. (2008): Evaluation of occupational safety and health in surface mines. Safety Science, 46, 1016-1024.

Wu, Q., Xie, K., and Chen, Z. (2012): A catastrophe model on the evaluation and classification of mine disaster rescue measures. Systems Engineering Procedia, 4, 484-489.

Yarahmadi, R., Bagherpour, R., and Khademian, A. (2014): Safety risk assessment of Iran's dimension stone quarries (Exploited by diamond wire cutting method): Safety Science, 63, 146-150.

Yari, M., Bagherpour, R., and Jamali, S. (2015): Development of an evaluation system for blasting patterns to provide efficient production. Journal of Intelligent Manufacturing, 1-10.

Yari, M., Bagherpour, R., Jamali, S., and Asadi, F. (2015): Selection of Most Proper Blasting Pattern in Mines Using Linear Assignment Method: Sungun Copper Mine. Archives of Mining Sciences, 60, 375-386.

Yari, M., Monjezi, M., and Bagherpour, R. (2013): Selecting the most suitable blasting pattern using AHP-TOPSIS method: sungun copper mine. Journal of Mining Science, 49, 967-975.

Yari, M., Monjezi, M., and Bagherpour, R. (2014b): A novel investigation in blasting operation management using decision making methods. Rudarsko-Geolosko-Naftni Zbornik, 29, 69.

Yari, M., Monjezi, M., Bagherpour, R., and Jamali, S. (2014): Developing a mathematical assessment model for blasting patterns management: Sungun copper mine. Journal of Central South University, 21, 4344-4351. 
Yavuz Çelik, M., and Sabah, E. (2008): Geological and technical characterisation of Iscehisar (Afyon-Turkey) marble deposits and the impact of marble waste on environmental pollution. Journal of environmental management, 87, 106-116.

Yong Jeong, B. (1999): Comparisons of variables between fatal and nonfatal accidents in manufacturing industry. International Journal of Industrial Ergonomics, 23, 565-572.

\section{Sažetak}

\section{Način procjene i klasifikacije kamenoloma oblikovanoga kamena s naglaskom na sigurnosne parametre}

Građevinski, oblikovani i ukrasni kamen te kamenolomi iz kojih se pridobivaju pripadaju važnoj gospodarskoj grani u Iranu. Danas je ta zemlja, nakon Kine i Italije, na trećemu mjestu po pridobivanju takvih sirovina u svijetu. Međutim, u svjetskoj trgovini takvim kamenjem sudjeluje sa znatno manjim udjelom. Jedan je od razloga nedostatak predstavljanja aktivnosti vezanih uz tu gospodarsku granu inozemnim kupcima. Nadalje, broj nesreća, s ozbiljnim i manjim posljedicama, pokazao je kako se njihovu sprječavanju mora posvetiti više pozornosti. Prvi korak u tome je prepoznavanje svih onih faktora koji na to mogu utjecati te rangiranje najvećih kamenoloma po sigurnosnim kriterijima. Stoga je ovdje prikazan opsežan model za rangiranje kamenoloma, u kojemu su izdvojene sve nužne varijable važne za sigurnost rada. U cilju provjere modela analizirano je 19 kamenoloma koje vodi tvrtka Pyrtak u provinciji Lorestan. Nakon određivanja uvjeta u kamenolomima ukrasnoga kamena i određivanja njihova utjecaja primijenjena je metoda AHP-TOPSIS koja se temelji na neizravnoj logici. Kamenolomi su rangirani prema rezultatima te je izdvojen onaj s najprimjerenijim načinom rudarenja.

\section{Ključne riječi}

oblikovani kamen, višekriterijsko odlučivanje (MCDM), kamenolom 